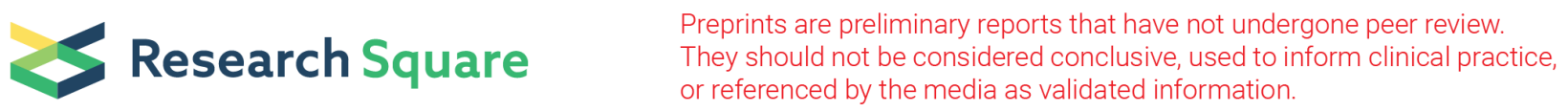

\title{
Chitosan Depolymerization: A Simple and Promising Chemical Process for the Preparation of Bioactive Varying Molecular Weight Derivatives
}

\section{Sawsan Affes}

ENIS: Ecole Nationale d'Ingenieurs de Sfax

Hana Maalej ( $\nabla$ hannou25@yahoo.fr)

ENIS: Ecole Nationale d'Ingenieurs de Sfax

Inmaculada Aranaz

Complutense University of Madrid: Universidad Complutense de Madrid

Niuris Acosta

Complutense University of Madrid: Universidad Complutense de Madrid

Ángeles Heras

Complutense University of Madrid: Universidad Complutense de Madrid

Moncef Nasri

ENIS: Ecole Nationale d'Ingenieurs de Sfax

\section{Research Article}

Keywords: Chitosan, Chemical depolymerization, Chitosan derivatives, Physicochemical characterization, Biological activity.

Posted Date: April 13th, 2021

DOI: https://doi.org/10.21203/rs.3.rs-371342/v1

License: (c) (i) This work is licensed under a Creative Commons Attribution 4.0 International License. Read Full License 


\begin{abstract}
In order to improve functional and biological properties of shrimp chitosan and to facilitate its utilization, chitosan derivatives were prepared by chemical depolymerization using hydrochloric acid $(6 \mathrm{M})$ during $2 \mathrm{~h}$. The obtained chitosan depolymerization products (CDP) were characterized in terms of molecular weight (Mw), acetylation (AD) and polymerization (DP) degrees, solubility, viscosity and crystallinity, and analyzed by FTIR spectroscopy. High Mw-CDP varying from 396 to $94 \mathrm{kDa}$ and low Mw-CDP (<4.4 kDa), with a DP up to 6 determined by MALDI-TOF, were withdrawn at different hydrolysis time and then desalted on chromatography Sephadex G-25 column. It is clearly demonstrated that the viscosity, the AD and the crystallinity decreased upon depolymerization, especially in low Mw-CDP. While, solubility in water and acetic acid were highly improved. FTIR analysis showed similar spectra of chitosan and CDP. The antibacterial, antifungal and antioxidant properties of CDP were investigated and demonstrated that they were related to its Mw. Indeed, as compared to chitosan, high Mw derivatives, especially C120, possess higher antibacterial and antifungal potentials. While, low Mw-CDP, especially H120, exhibited the highest antioxidant properties. Interestingly, the used chemical depolymerization process seems to be an efficient, simple and easy method to produce bioactive chitosan derivatives with attractive characteristics to be applied in an industrial scale, especially as functional-food components.
\end{abstract}

\title{
1. Introduction
}

Chitosan is one of the most abundant renewable polysaccharides which is prepared from chitin by deacetylation and composed of $\beta$-1,4-linked glucosamine with various degrees of $\mathrm{N}$-acetylated residues $[1,2]$. This polymer is attracting a wide attention due to its biodegradability and non-toxicity that make it suitable for use in a wide variety of applications, such as biomedical, pharmacological, agricultural and biotechnological industries [3, 4, 5, 6]. However, its poor solubility in water and various aqueous solutions restricts many of its potential applications $[7,8]$.

Recently, chitosan depolymerization products (CDP) have attracted much more interest, because they are not only more soluble in aqueous solutions and possess lower molecular weight ( $\mathrm{Mw}$ ), but also exhibit interesting biological activities, such as antitumor, antifungal and antibacterial properties, as well as immune-enhancing effects on animal health $[9,10,4,2]$. Although some reports mention that the biological potential of CDP depends on their structure, especially their $\mathrm{Mw}$, acetylation (AD) and polymerization degrees (DP) [11, 2, 12].

Chitosan derivatives have been synthesized by several technological approaches, such as physical, enzymatic and chemical methods. Physical approaches use the microwave and ultrasound energy for chitosan hydrolysis, but they are not often used commercially because of their energy-intensive nature [13, 14]. Chito-oligomers preparation can be achieved by enzymatic hydrolysis using specific enzymes $[15,16,7,17]$, however, this method is limited due to the high cost and not availability of chitosanases. The hydrolysis of chitosan was further studied using different other commercial non-specific enzymes, such as chitinase [18, 19], lysozyme, papain, cellulose [20], lipase [21], while, these enzymes, were added at high concentrations.

To overcome these limitations, chitosan hydrolysis by acids, mainly acetic acid [9], nitrous acid [22], phosphoric acid, hydrogen fluoride [8] and hydrochloric acid $(\mathrm{HCl})[23,11]$ has been evaluated as simple, easy and practical method. Industrially, acid hydrolysis with $\mathrm{HCl}$ is preferred, since it is relatively simple, easy, practical and gives a high yield $[23,24]$. It is previously reported that $\mathrm{HCl}$ not only breaks the glycosidic bonds in chitosan chains but also hydrolyzes the $\mathrm{N}$ acetyl amide groups to give chitosan chains with lower $\mathrm{Mw}$ and $\mathrm{AD}$. Indeed, the acid concentration, the reaction time and the used temperature are considered among the most crucial factors of the acid hydrolysis process $[23,9]$.

In the present study, chitosan derivatives (CDP) with varying characteristics were prepared by chemical hydrolysis of shrimp chitosan using $\mathrm{HCl}$ (6 $\mathrm{M}$ ). The antimicrobial effect of the obtained CDP, compared to chitosan, was investigated against seven pathogenic bacteria and two fungi, which were mostly putrefactive microorganisms in food and aquatic preservation. Moreover, their antioxidant potential through different mechanisms was also studied.

\section{Materials And Methods}

\subsection{Reagents and chemicals}

D-glucosamine hydrochloride and N-acetyl-glucosamine, the monomer unit of chitosan structure, were from Sigma Chemical Co. (USA). All other chemicals and reagents were of analytical grade. Shrimp chitosan was prepared as described in our previous study [25] and used as substrate for the chemical production of varying Mw chitosan derivatives. Prior to use, shrimp shells (SS) were washed thoroughly with tap water to remove contaminants, desiccated at room temperature and then milled to powder in a Moulinex® blender. For chitin extraction, minerals, associated to SS, were firstly removed by chemical demineralization using three successive $0.5 \mathrm{M} \mathrm{HCl}$ baths at a ratio of $1: 10(\mathrm{w} / \mathrm{v})$ at $4^{\circ} \mathrm{C}$ with stirring at $30 \mathrm{rpm}$ for $30 \mathrm{~min}$. In a second step, chemical deproteinization of the demineralized material was carried out under standard autoclaving conditions at $121^{\circ} \mathrm{C}$ using $10 \%(\mathrm{w} / \mathrm{v}) \mathrm{NaOH}$. The deacetylation of the obtained chitin was performed by treatment with $12.5 \mathrm{M} \mathrm{NaOH}$ at a ratio of $1: 10(\mathrm{w} / \mathrm{v})$ for $4 \mathrm{~h}$ at $140^{\circ} \mathrm{C}$. After filtration, the residue was washed with distilled water until neutral $\mathrm{pH}$ was reached, and finally dried at $45^{\circ} \mathrm{C}$ overnight to obtain shrimp chitosan.

\subsection{Chitosan hydrolysis process}

Chitosan depolymerization products (CDP) were prepared by acid hydrolysis of shrimp chitosan using hydrochloric acid ( $\mathrm{HCl})$ as described by Li et al. [11] with some modifications. Chitosan $(20 \mathrm{~g})$ was added to $600 \mathrm{ml}$ of $\mathrm{HCl}$ solution $(6 \mathrm{M})$. The obtained mixture was heated in a $70^{\circ} \mathrm{C}$ bath under stirring for $2 \mathrm{~h}$. Samples were periodically withdrawn at regular time intervals $(30,60,90,120$ and 240 min), adjusted to $\mathrm{pH} 8.0$ with concentrated $\mathrm{NaOH}$ and centrifuged at 8000 x g during $30 \mathrm{~min}$. The insoluble parts, obtained at 30, 60, 90 and $120 \mathrm{~min}$, were freeze dried and referred as high Mw-CDP: C30, C60, C90 and C120, respectively. The soluble parts were concentrated on a rotary evaporator to remove the $\mathrm{HCl}$.

\subsection{Desalination of soluble parts by gel filtration chromatography G-25}


In order to remove salts, the insoluble parts, considered as low Mw-CDP, were desalted on a size exclusion chromatography Sephadex G-25 column (100 x 13 $\mathrm{mm}$ ). The column was eluted with ultrapure water with a flow of $0.5 \mathrm{ml} / \mathrm{min}$. Elution was monitored spectrophotometrically by measuring the absorbance under UV light (OD $260 \mathrm{~nm}$ ) and the reducing sugar content (SR mg/g chitosane), by the modified dinitrosalycilic acid (DNS) method using glucosamine as standard [24], in each collected tube ( $5 \mathrm{ml})$. The elution profiles of OD $260 \mathrm{~nm}$ and SR were graphed as function of the volume (each $5 \mathrm{ml}$ ). After $\mathrm{G} 25$, the collected fractions obtained after $30,60,90$ and 120 min of hydrolysis were freeze-dried and referred as H30, H60, H90 and H120, respectively.

\subsection{Physico-chemical characterization of chitosan and CDP}

\subsubsection{Molecular weight determination by steric exclusion chromatography (SEC-HPLC)}

SEC-HPLC was performed with Waters $625 \mathrm{LC}$ System Pump using an Ultrahydrogel column (I.D $=7.8 \mathrm{~mm}, \mathrm{I}=300 \mathrm{~mm})$ thermostated at $35^{\circ} \mathrm{C}$ and connected to a Waters 2414 differential refractometer. Samples were dissolved in $0.15 \mathrm{M}$ ammonium acetate/0.2 M acetic acid buffer ( $\mathrm{pH} 4.5$ ), at a concentration of $0.2 \%$ $(\mathrm{w} / \mathrm{v})$, filtered through a $0.45 \mu \mathrm{m}$ pore size membrane (Millipore Corporation, Beverly, MA, USA) before injection of aliquots of $20 \mu \mathrm{l}$. The flow rate was 0.6 $\mathrm{ml} / \mathrm{min}$. The molecular weights $(\mathrm{Mw})$ of the different samples were obtained from the SEC profiles by extrapolation in a calibration curve using different known Mw dextrans as standards.

\subsubsection{Mass spectrometric analysis (MALDI-TOF MS) of low Mw-CDP}

MALDI-TOF MS was performed using an Autoflex Speed MALDI-TOF mass spectrometer (Bruker Daltonics, Germany) equipped with a Smart Beam TM ND YAG-laser $(355 \mathrm{~nm})$ in the positive ion mode. For ionization, 2,5-dihydroxybenzoic acid was used as matrix. All spectra were obtained in reflection mode with an acceleration voltage of $25 \mathrm{kV}$, a reflector voltage of $26 \mathrm{kV}$ and pulsed ion extraction of $40 \mathrm{~ns}$ in positive ion mode. The acquisition range was m/z $50-4000$. The data were obtained by taking the average value of 500 laser shots, with the lowest laser energy necessary to obtain sufficient signal-to-noise ratios [2].

\subsubsection{Acetylation degree measurement}

The potentiometric determination of the acetylation degree (AD) was carried out following the first derivative UV spectrophotometric method given by Muzzarelli et al. [27]. UV measurements were carried out in a spectrophotometer in the wavelength range 190-240 nm. A calibration curve of N-acetylglucosamine (10-40 ppm) and samples, at a concentration of $0.1 \%(\mathrm{w} / \mathrm{v})$, were prepared in $0.01 \mathrm{M}$ acetic acid.

\subsubsection{Functional properties evaluation}

The intrinsic viscosity [ $\eta$ ] of chitosan and its derivatives was studied according to Rinaudo et al. [28] using a semi-automatic Ubbelohde viscometer at 25 ( \pm $0.2){ }^{\circ} \mathrm{C}$. Different concentrations $(1.0-5.0 \mathrm{mg} / \mathrm{ml})$ were prepared in an acetic acid $(0.3 \mathrm{M})$ /sodium acetate $(0.2 \mathrm{M})$ buffer $(\mathrm{pH} 4.5)$ (five determinations per concentration). The $[\eta](\mathrm{ml} / \mathrm{g})$ was estimated by extrapolation and averaging from the Huggins equation:

$\eta \mathrm{sp} / \mathrm{C}=[\eta]+[\eta]^{2} \times \mathrm{k}_{\mathrm{H}} \times \mathrm{C}$

Where $\eta \mathrm{sp} / \mathrm{C}$ is the reduced viscosity $(\mathrm{ml} / \mathrm{g}) ; \mathrm{k}_{\mathrm{H}}$ is the Huggins' coefficient and $\mathrm{C}$ is the sample concentration $(\mathrm{g} / \mathrm{ml})$.

The solubility in water and acetic acid (1\%) was performed according to the method of Fernandez-Kim [29]. The solubility of the sample was determined and calculated using the following equation:

Solubility $(\%)=\frac{\left(W_{1}-W_{2}\right)}{\left(W_{1}-W_{0}\right)} \times 100$

Where $W_{1}$ and $W_{2}$ are the initial and final tube weights containing sample, respectively, and $W_{0}$ is the initial tube mass.

\subsubsection{X-ray diffraction measurements (XRD)}

XRD patterns were performed using an X-ray diffractometer (Philips X'Pert SW) equipped with a copper anode. Samples were continuously scanned from 0 to $50^{\circ}(2 \theta)$ at $45 \mathrm{kV}$ and $40 \mathrm{~mA}$. The crystallinity index (Crl) was calculated as described by Focher et al. [30]:

$$
\operatorname{CrI}(\%)=\frac{\left(\mathrm{I}_{110}-\mathrm{I}_{\mathrm{am}}\right)}{\mathrm{I}_{110}} \times 100
$$

Where $\mathrm{I}_{110}$ is the crystallinity diffraction intensity at $2 \theta=20^{\circ}$ and $\mathrm{I}_{\mathrm{am}}$ is the amorphous diffraction intensity at $2 \theta=16^{\circ}$.

\subsubsection{Fourier-transform infrared spectroscopy analysis (FTIR)}

FTIR spectra were recorded at $25^{\circ} \mathrm{C}$, in the spectral range frequencies of $500-4000 \mathrm{~cm}^{-1}$ and at a resolution of $4 \mathrm{~cm}^{-1}$, on a Performer Spectra Tech spectrometer (Agilent Technologies, Carry 630 series) linked to an attenuated total reflectance accessory with a diamond crystal. Calibration was done using background spectrum recorded from the clean and empty cell.

\subsection{Biological properties evaluation}

\subsubsection{Antimicrobial activity}

The antimicrobial activity of chitosan and CDP was tested against three Gram-negative bacteria: Salmonella enterica (ATCC 14028), Pseudomonas aeruginosa (ATCC 49189) and Enterobacter sp, four Gram-positive bacteria: Staphylococcus aureus (ATCC 6538), Micrococcus luteus (ATCC 14110), Listeria monocytogenes (ATCC 19117) and Bacillus cereus (ATCC 11778) as well as two fungi: Fusarium solani and Rhizoctonia solani. 
The agar well diffusion method was firstly performed, at $50 \mathrm{mg} / \mathrm{ml}$ of sample concentration, as described by Vanden Berghe \& Vlietinck [31] on a MuellerHinton and malt-extract agar medium for antibacterial and antifungal activities, respectively. Acetic acid (0.1\%) was used as negative control and gentamicin and cycloheximide were used as positive controls for antibacterial and antifungal activity, respectively. The diameter of the growth inhibition zone around each well (including well diameter of $6 \mathrm{~mm}$ ) was measured and reported as the antimicrobial activity.

Further, the minimum inhibitory concentration (MIC) of chitosan and CDP, defined as the lowest sample concentration that inhibited the visible growth of tested bacteria after $24 \mathrm{~h}$, was determined by liquid growth inhibition assay in a sterile 96-well microplates assay system according to Farag et al. [32]. The minimum bactericide concentration (MBC), which determines the sufficient sample concentration to destroy $99.99 \%$ of the microorganism population, was also studied. MIC and MBC values are expressed in \% (or in g/100 ml).

\subsubsection{Antioxidant activity}

\subsubsection{DPPH and ABTS radical scavenging potentials}

The ability of chitosan and its derivatives to scavenge 1,1-diphenyl-2-picrylhydrazyl (DPPH) radical was estimated using the method described by Bersuder et al. [33].

The capacity of chitosan and CDP to quench the long-lived 2,2'-Azino-bis (3-ethylbenzothiazoline-6-sulfonic acid) (ABTS ${ }^{+}$) species was also studied according to the method of Re et al. [34]. The DPPH and $\mathrm{ABTS}^{+}$scavenging activities were expressed as the $50 \%$ effective concentration (IC $\left.{ }_{50}\right)(\mathrm{mg} / \mathrm{ml})$. Butylated hydroxyl-anisole (BHA) was used as a positive control.

\subsubsection{Reducing power activity}

The ability of BHA, chitosan and its derivatives to reduce iron (III) was evaluated according to the method described by Yildirim et al. [35]. Higher absorbance of the reaction mixture showed higher reducing power. The reducing power activity was reported as the effective concentration which allows to obtain an absorbance of 0.5 .

\subsubsection{Total antioxidant assay}

The total antioxidant ability of chitosan and $\mathrm{CDP}$ to reduce $\mathrm{Mo}(\mathrm{VI})$ to $\mathrm{Mo}(\mathrm{V})$ and to form a phosphate/Mo ( $\mathrm{V})$ complex at acidic pH was tested as reported by Prieto et al. [36]. The total antioxidant activity was reported as a-tocopherol equivalents and BHA was used as a positive control.

\subsection{Statistical analysis}

All experiments were carried out in triplicate, and average values with standard deviation errors are reported. Mean separation and significance were analyzed using the SPSS software package ver. 17.0 professional edition (SPSS, Inc., Chicago, IL, USA) using ANOVA analysis with Duncan post hoc testes. Differences were considered significant at $p<0.05$.

\section{Results And Discussion}

\subsection{Preparation of CDP by acid depolymerization of chitosan}

Among the different methods of chitosan depolymerization, acid hydrolysis with $\mathrm{HCl}$ is preferred, especially on an industrial scale [23, 8]. Varying Mw-CDP were prepared from shrimp chitosan by using $\mathrm{HCl}(6 \mathrm{M})$. The hydrolysis reaction was carried out for different time intervals in order to determine the reaction time needed to obtain CDP with certain characteristics. After hydrolysis, the insoluble compounds were named C30, C60, C90 and C120, obtained at 30, 60, 90, 120 and 240 min, respectively.

While, the soluble parts were desalted on an exclusion chromatography $\mathrm{G} 25$. To collect the desalted fractions, the absorbance under $\mathrm{UV}_{\mathrm{V}}$ light at $\mathrm{OD}_{260} \mathrm{~nm}$ and the reducing sugar amount in each obtained fraction (of $5 \mathrm{ml}$ ), were measured and results are depicted in Fig. $\mathbf{S 1}$. The collected fractions were freeze-dried and named H30 (tubes from 20 to 110), H60 (tubes from 20 to 103), H90 (tubes from 20 to 107) and H120 (tubes from 20 to 75), obtained at $30,60,90,120$ and 240 min, respectively.

\subsection{Physicochemical characterization of CDP}

The Mw reduction of samples withdrawn during chitosan hydrolysis was followed by SEC-HPLC analysis, and the obtained average Mw values are given in Table 1. The chromatograms of SEC (Fig. 1) showed that the peak of the elution curve of the original chitosan ( $\mathrm{Mw}=1244.70 \mathrm{kDa})$ shifted towards longer retention time as the Mw of CDP decreased evidencing depolymerization. Results revealed that insoluble parts obtained after chitosan hydrolysis and recovered at different incubation times (30,60, 90 and $120 \mathrm{~min}$ ), exhibited an average Mw of 396.46, 170.65, 109.63 and 94.10 kDa for C30, C60, C90 and C120, respectively. These compounds were referred as high Mw-CDP. While, SEC-HPLC analysis of the desalted and freeze-dried soluble parts showed that in all cases, the retention times were out of the dextran calibration curve showing a Mw lower than $4.4 \mathrm{kDa}$. These samples were considered as low Mw-CDP. 
Table 1

Average molecular weight (Mw), intrinsic viscosity, acetylation degree (AD), acetic acid (AS) and water

(WS) solubilities and crystallinity index (Crl) of chitosan and its derivatives obtained by chemical

\begin{tabular}{|c|c|c|c|c|c|c|}
\hline Sample & $\mathrm{Mw}(\mathrm{kDa})$ & Viscosity (dl/g) & $A D(\%)$ & AS (\%) & WS (\%) & $\mathrm{Crl}(\%)$ \\
\hline Chitosan & 1244.70 & $7.81 \pm 0.21$ & $7.60 \pm 0.54^{a}$ & $75.89 \pm 0.83$ & $15.09 \pm 0.06$ & 74.40 \\
\hline C30 & 396.46 & $2.07 \pm 0.02$ & $7.50 \pm 0.60^{a}$ & $96.52 \pm 0.26$ & $18.04 \pm 0.03$ & 45.25 \\
\hline C60 & 170.65 & $1.44 \pm 0.04$ & $6.66 \pm 0.04^{a b}$ & $98.20 \pm 0.97$ & $18.46 \pm 0.03$ & ND \\
\hline C90 & 109.63 & $1.12 \pm 0.00$ & $6.63 \pm 0.04^{a b}$ & $99.65 \pm 0.49$ & $19.59 \pm 0.08$ & ND \\
\hline C120 & 94.10 & $0.66 \pm 0.01$ & $5.94 \pm 0.15^{b}$ & $99.75 \pm 0.35$ & $21.07 \pm 0.16$ & 25.76 \\
\hline H30 & $<4.4$ & ND & $4.32 \pm 0.06^{c}$ & $100 \pm 0.00$ & $100 \pm 0.00$ & ND \\
\hline $\mathrm{H} 60$ & $<4.4$ & ND & $5.00 \pm 0.19^{c}$ & $100 \pm 0.00$ & $100 \pm 0.00$ & ND \\
\hline $\mathrm{H} 90$ & $<4.4$ & ND & $4.93 \pm 0.01^{c}$ & $100 \pm 0.00$ & $100 \pm 0.00$ & ND \\
\hline H120 & $<4.4$ & ND & $4.76 \pm 0.11^{\mathrm{c}}$ & $100 \pm 0.00$ & $100 \pm 0.00$ & ND \\
\hline \multicolumn{7}{|c|}{ Values are means \pm standard deviation $(n=3)$} \\
\hline \multicolumn{7}{|c|}{ ND indicates data were not determined. } \\
\hline Means wi & ent & $(\mathrm{a}-\mathrm{c}) \mathrm{a}$ & column in & significant & erence $(p<$ & 5). \\
\hline
\end{tabular}

In order to evaluate the oligomer composition of low Mw-CDP, samples were analyzed by MALDI-TOF MS and identified as sodium adducts [M + Na] $]^{+}$. The assigned structure of each sample is given in Table 2. It appeared that during hydrolysis, the O-glycosidic and the N-acetyl linkages between chitosan residues are chemically-hydrolyzed, leading to a mixture of acetylated (GlcNac-oligomers) (A) and deacetylated chito-oligomers (GlcN-oligomers) (D) with DP up to 7. After $2 \mathrm{~h}$ of hydrolysis, the yielded products, generated by chemical hydrolysis of chitosan were a mixture of hetero-chito-oligomers with DP 2, 3, 4 and 5 containing (GlcN) $)_{2}$ (D2), (GlcN)-GlcNac (D1A1), (GlcN) $)_{3}(\mathrm{D} 3),(\mathrm{GlcN})_{2}-\mathrm{GlcNac}(\mathrm{D} 2 \mathrm{~A} 1), \mathrm{GlcN}-(\mathrm{GlcNac})_{2}(\mathrm{D} 1 \mathrm{~A} 2),(\mathrm{GlcNac})_{3}(\mathrm{~A} 3),(\mathrm{GlcN})_{4}(\mathrm{D} 4),(\mathrm{GlcN})_{3}-\mathrm{GlcNac}$ (D3A1), $(\mathrm{GlcN})_{2}-(\mathrm{GlcNac})_{2}(\mathrm{D} 2 \mathrm{~A} 2), \mathrm{GlcN}-(\mathrm{GlcNac})_{3}(\mathrm{D} 1 \mathrm{~A} 3),(\mathrm{GlcNac})_{4}(\mathrm{~A} 4),(\mathrm{GlcN})_{4}(\mathrm{GlcNac})_{1}(\mathrm{D} 4 \mathrm{~A} 1),(\mathrm{GlcN})_{6}$ (D6) as the major components. 
Table 2

Ion composition (\%) of desalted low Mw-CDP prepared by chemical hydrolysis of shrimp chitosan at different hydrolysis times $(30,60,90$

\begin{tabular}{|c|c|c|c|c|c|c|}
\hline \multirow{2}{*}{$\begin{array}{l}\mathrm{m} / \mathrm{z} \\
{[\mathrm{M}+\mathrm{Na}]^{+}}\end{array}$} & \multicolumn{2}{|c|}{ Ion composition } & \multicolumn{4}{|c|}{ Intensity } \\
\hline & & & $\mathrm{H} 30$ & $\mathrm{H} 60$ & $\mathrm{H} 90$ & $\mathrm{H} 120$ \\
\hline 363.14 & 2 & $(\mathrm{GlcN})_{2}$ & 15 & 12 & 12 & 10 \\
\hline 405.15 & 2 & $(\mathrm{GlcN})-\mathrm{GlcNac}$ & 14 & 14 & 11 & 13 \\
\hline 447.16 & 2 & $(\mathrm{GlcNac})_{2}$ & 29 & 15 & 10 & \\
\hline 524.21 & 3 & $(\mathrm{GlcN})_{3}$ & 27 & 24 & 13 & 22 \\
\hline 566.22 & 3 & $(\mathrm{GlcN})_{2}-\mathrm{GlcNac}$ & 15 & 18 & 33 & 23 \\
\hline 608.23 & 3 & $\mathrm{GlcN}-(\mathrm{GlcNac})_{2}$ & 46 & 59 & 57 & 53 \\
\hline 650.24 & 3 & $(\mathrm{GlcNac})_{3}$ & 37 & 48 & 44 & 20 \\
\hline 685.27 & 4 & $(\mathrm{GlcN})_{4}$ & 18 & 17 & 22 & 19 \\
\hline 727.27 & 4 & $(\mathrm{GlcN})_{3}-\mathrm{GlcNac}$ & 21 & 49 & 26 & 14 \\
\hline 769.29 & 4 & $(\mathrm{GlcN})_{2}-(\mathrm{GlcNac})_{2}$ & 11 & 40 & 22 & 15 \\
\hline 811.3 & 4 & $\mathrm{GlcN}-(\mathrm{GlcNac})_{3}$ & 13 & 81 & 13 & 11 \\
\hline 853.31 & 4 & $(\mathrm{GlcNac})_{4}$ & 17 & 27 & & 21 \\
\hline 846.34 & 5 & $(\mathrm{GlcN})_{5}$ & 16 & 17 & 17 & \\
\hline 888.35 & 5 & $(\mathrm{GlcN})_{4}-(\mathrm{GlcNac})_{1}$ & 16 & & & 18 \\
\hline 930.36 & 5 & $(\mathrm{GlcN})_{3}-(\mathrm{GlcNac})_{2}$ & 10 & & & \\
\hline 972.37 & 5 & $(\mathrm{GlcN})_{2}-(\mathrm{GlcNac})_{3}$ & 14 & & & \\
\hline 1056.39 & 5 & $(\mathrm{GlcNac})_{5}$ & 17 & 10 & & \\
\hline 1007.41 & 6 & $(\mathrm{GlcN})_{6}$ & 18 & 17 & 15 & 10 \\
\hline 1049.42 & 6 & $(\mathrm{GlcN})_{5}-(\mathrm{GlcNac})_{1}$ & 10 & & & \\
\hline 1091.43 & 6 & $(\mathrm{GlcN})_{4}-(\mathrm{GlcNac})_{2}$ & 10 & & & \\
\hline 1175.45 & 6 & $(\mathrm{GlcN})_{2}-(\mathrm{GlcNac})_{4}$ & 13 & & & \\
\hline 1217.46 & 6 & $(\mathrm{GlcN})_{1}-(\mathrm{GlcNac})_{5}$ & 14 & & & \\
\hline 1210.49 & 7 & $(\mathrm{GlcN})_{6}-(\mathrm{GlcNac})_{1}$ & 10 & & & \\
\hline
\end{tabular}

The acetylation degree $(A D)$ of chitosan and its derivatives was further determined and results are depicted in Table 1. It appeared that there is no significant difference in AD between chitosan and high Mw-CDP ( $p>0.05)$, except of C120 in which the AD slightly decreased $(p<0.05)$. However, all low Mw-CDP showed a significant decrease in the AD values as compared to chitosan and high Mw-CDP. The decrease of the AD in chitosan derivatives obtained by acid hydrolysis was previously reported [23].

Moreover, the hydrolysis of chitosan was highlighted by the significant decrease in the intrinsic viscosity of chitosan (7.81 $\pm 0.21 \mathrm{dl} / \mathrm{g})$ as compared to CDP, which is correlated with the decrease in Mw. Results, illustrated in Table 1, showed that the decrease of the viscosity of high Mw-CDP was more pronounced during the first $30 \mathrm{~min}(2.07 \mathrm{dl} / \mathrm{g})$, followed by a slow decrease during the rest of the reaction ( $0.66 \pm 0.01 \mathrm{dl} / \mathrm{g}$ for C120). While, low Mw-CDP are not viscous.

In addition, solubility in acetic acid (1\%) and water of chitosan and CDP were studied. Results illustrated in Table 1 showed that, as expected, the samples solubility increases with the Mw decrease. Contrarily to chitosan, high Mw-CDP are soluble in acetic acid (1\%), while, they exhibited a poor water solubility (< $22 \%$ ) (Table 1). However, low Mw-CDP were totally soluble in acetic acid 1\% and water (100\%). The reason for the increased solubility of chitosan derivatives was the destruction of intra macromolecular and inter chain hydrogen bonds, which alters the secondary structure of chitosan, decreasing its crystallinity and unfolding its molecular chains [1].

Besides, the acid degradation of chitosan was accompanied by a decrease in the crystallinity. The x-ray diffraction patterns of chitosan and high Mw-CDP (C30 and C120) are illustrated in Fig. 2. Chitosan exhibited two crystalline peaks at $2 \theta=10$ and $20^{\circ}$, which corresponded to its hydrated polymorphe structure, with a crystallinity index (Crl) of 74.4\% (Table 1). However, after chemical hydrolysis, the crystallinity decreased in C30 and C120, showing a less intense peak 
at $2 \theta=20^{\circ}$, while the peak at $2 \theta=10^{\circ}$ disappeared, suggesting their amorphous structure. The $\mathrm{Crl}$ of $\mathrm{C} 30$ and $\mathrm{C} 120$ were 45.25 and $25.76 \%$, respectively (Table 1). Low Mw-CDP are not crystalline (Data not shown).

The physicochemical properties of chitosan and CDP (C30, C120, H30 and H120) were also studied by FTIR analysis, showing similar spectra and confirming the conservation of the basic structure of chitosan during hydrolysis. FTIR spectra (Fig. 3) showed characteristic absorption bands at 3370 and $3296 \mathrm{~cm}^{-1}$ attributed to the stretching vibration of $-\mathrm{OH}$ and $\mathrm{NH}$ groups, respectively. The small peak at around $2875 \mathrm{~cm}^{-1}$ was ascribed as $\mathrm{CH}_{2}$ and $\mathrm{CH}_{3}$ groups. The signal observed at $1650 \mathrm{~cm}^{-1}$ was characteristic of the amide I band ( $\mathrm{C}=\mathrm{O}$ in the $\mathrm{NH}-\mathrm{COCH}_{3}$ group). At around $1562 \mathrm{~cm}^{-1}$, appeared the band of amine ( $\mathrm{NH}$ ). The peak at around $1420 \mathrm{~cm}^{-1}$ was characteristic to the $\mathrm{C}-\mathrm{H}$ bending vibration of $\mathrm{CH}_{2}$ groups. Similar FTIR spectra of chitosan and its derivatives were obtained by Affes et al. [25] and Li et al. [37].

\subsection{Biological properties evaluation}

\subsubsection{Antibacterial potential}

The antibacterial potential of chitosan and its derivatives was firstly performed using the agar well diffusion method. Results reported in Table 3 showed that chitosan and all CDP inhibited the growth of the seven studied pathogenic bacteria, with varying diameters of inhibition and with higher inhibitory potential against Gram (-) than Gram (+) strains. Moreover, the resistance of the bacterial strains tested towards chitosan and its derivatives decreased in the following order: B. cereus $>$ M. luteus $>$ L. monocytogenes $>$ S. aureus $>E$. $s p>S$. enterica $>$ P. aeruginosa. Further, high Mw-CDP, especially C120 $(\mathrm{Mw}=94.10 \mathrm{kDa}, \mathrm{AD}=$ $5.94 \%)$, possess significantly higher diameters of growth inhibition comparing to chitosan and low Mw-CDP $(p<0.05)$. For the strains $S$. enterica, $P$. aeruginosa and L. monocytogenes, $\mathrm{C} 120$ showed similar antagonistic effect than that of the positive control gentamycin $(p>0.05)$.

Table 3

Antimicrobial potential of chitosan and CDP samples, through agar diffusion method, against various bacteria and fungi at $50 \mathrm{mg} / \mathrm{ml}$

Diameter of inhibition zone ( $\mathrm{mm})$

\begin{tabular}{|c|c|c|c|c|c|c|c|c|c|}
\hline \multirow{3}{*}{$\begin{array}{l}\text { Strain } \\
\text { Sample }\end{array}$} & \multicolumn{9}{|c|}{ Diameter of inhibition zone $(\mathrm{mm})$} \\
\hline & \multicolumn{3}{|c|}{ Gram (-) bacteria } & \multicolumn{4}{|l|}{ Gram (+) bacteria } & \multicolumn{2}{|l|}{ Fungi } \\
\hline & $\begin{array}{l}\text { Salmonella } \\
\text { enterica }\end{array}$ & $\begin{array}{l}\text { Pseudomonas } \\
\text { aeruginosa }\end{array}$ & $\begin{array}{l}\text { Enterobacter } \\
\mathrm{sp}\end{array}$ & $\begin{array}{l}\text { Staphylococcus } \\
\text { aureus }\end{array}$ & $\begin{array}{l}\text { Micrococcus } \\
\text { luteus }\end{array}$ & $\begin{array}{l}\text { Listeria } \\
\text { Monocytogenes }\end{array}$ & $\begin{array}{l}\text { Bacillus } \\
\text { cereus }\end{array}$ & $\begin{array}{l}\text { Rhizoctonia } \\
\text { solani }\end{array}$ & $\begin{array}{l}\text { Fusarium } \\
\text { solani }\end{array}$ \\
\hline $\begin{array}{l}\text { Positive } \\
\text { control }\end{array}$ & $18^{a}$ & $18^{a}$ & $26^{a}$ & $25^{a}$ & $19^{a}$ & $16^{a}$ & $22^{a}$ & $22^{a}$ & $23^{a}$ \\
\hline Chitosan & $12.3 \pm 0.4^{g}$ & $13.3 \pm 0.4$ ef & $12.2 \pm 0.3$ ef & $11 \pm 0.7^{f}$ & $11.4 \pm 0.5^{\text {ef }}$ & $11.4 \pm 0.6^{c}$ & $\begin{array}{l}10.5 \pm \\
0.7^{d}\end{array}$ & $13.5 \pm 0.7^{\mathrm{e}}$ & $\begin{array}{l}13.3^{ \pm} \\
0.4^{c}\end{array}$ \\
\hline C30 & $\begin{array}{l}14.2 \pm 0.2 \\
\text { de }\end{array}$ & $14.6 \pm 0.5^{\mathrm{de}}$ & $13.3 \pm 0.5^{\mathrm{de}}$ & $13.2 \pm 0.3^{\mathrm{cd}}$ & $12.5 \pm 0.5 \mathrm{de}$ & $12.5 \pm 0.2^{c}$ & $\begin{array}{l}12.5^{ \pm} \\
0.5^{c}\end{array}$ & $14.9 \pm 0.2^{d}$ & $\begin{array}{l}15.0 \pm \\
0.5^{b}\end{array}$ \\
\hline $\mathrm{C60}$ & $\begin{array}{l}15.2 \pm 0.5 \\
\mathrm{~cd}\end{array}$ & $15.5 \pm 0.5^{\mathrm{cd}}$ & $14.5 \pm 0.5^{\mathrm{cd}}$ & $13.8 \pm 0.2^{c}$ & $13.7 \pm 0.3^{\mathrm{cd}}$ & $14.3 \pm 0.2^{b}$ & $\begin{array}{l}13.8 \pm \\
0.2^{b}\end{array}$ & $15.6 \pm 0.5^{\mathrm{cd}}$ & $\begin{array}{l}16.5 \pm \\
0.5^{b}\end{array}$ \\
\hline $\mathrm{C9O}$ & $\begin{array}{l}16.5 \pm 0.5 \\
b c\end{array}$ & $16.2 \pm 0.7^{b c}$ & $15.5 \pm 0.5^{b c}$ & $14.2 \pm 0.2^{c}$ & $14.8 \pm 0.5^{b c}$ & $15.5 \pm 0.3^{a}$ & $\begin{array}{l}14.5^{ \pm} \\
0.8^{b}\end{array}$ & $16.5 \pm 0.5^{b c}$ & $\begin{array}{l}17.4 \pm \\
0.7^{a b}\end{array}$ \\
\hline $\mathrm{C} 120$ & $\begin{array}{l}17.7 \pm 0.5 \\
\mathrm{ab}\end{array}$ & $17.6 \pm 0.2^{a b}$ & $16.3 \pm 0.5^{b}$ & $15.5 \pm 0.3^{b}$ & $15.5 \pm 0.5^{b}$ & $15.7 \pm 0.3^{a}$ & $\begin{array}{l}15.0^{ \pm} \\
0.5^{\mathrm{b}}\end{array}$ & $17.3 \pm 0.5^{b}$ & $\begin{array}{l}18.5 \pm \\
0.2^{a b}\end{array}$ \\
\hline H30 & $\begin{array}{l}13.8 \pm 0.6 \\
\text { def }\end{array}$ & $13.2 \pm 0.7$ ef & $12.2 \pm 0.4$ ef & $12.3 \pm 0.3$ de & $11.4 \pm 0.5$ ef & $11.5 \pm 0.2^{c}$ & $\begin{array}{l}10.8 \pm \\
0.2^{\mathrm{d}}\end{array}$ & $12.8 \pm 0.6$ ef & $\begin{array}{l}13.2 \pm \\
0.7^{b c}\end{array}$ \\
\hline $\mathrm{H} 60$ & $\begin{array}{l}13.5 \pm 0.2 \\
\text { efg }\end{array}$ & $13.0 \pm 0.3^{f}$ & $12.0 \pm 0.3^{\text {ef }}$ & $12.0 \pm 0.4^{a b}$ & $10.7 \pm 0.2^{\mathrm{fg}}$ & $10.2 \pm 0.4^{d}$ & $\begin{array}{l}10.6 \pm \\
0.2^{d}\end{array}$ & $12.5 \pm 0.2$ ef & $\begin{array}{l}13.0 \pm \\
0.3^{b c}\end{array}$ \\
\hline H9O & $12.5 \pm 0.5$ & $12.7 \pm 0.5^{f}$ & $11.8 \pm 0.2^{f}$ & $11.8 \pm 0.2^{\mathrm{ab}}$ & $10.2 \pm 0.3^{\mathrm{fg}}$ & $10.2 \pm 0.5^{d}$ & $\begin{array}{l}10.2 \pm \\
0.2^{d}\end{array}$ & $12.2 \pm 0.5^{\text {ef }}$ & $\begin{array}{l}12.7 \pm \\
0.5^{b c}\end{array}$ \\
\hline $\mathrm{H} 120$ & $\underset{f g}{12.4 \pm 0.3}$ & $12.5 \pm 0.2^{f}$ & $11.4 \pm 0.7^{f}$ & $11.6 \pm 0.4^{\mathrm{ab}}$ & $10.0 \pm 0.2^{g}$ & $10.0 \pm 0.3^{d}$ & $\begin{array}{l}9.5 \pm \\
0.3^{d}\end{array}$ & $11.7 \pm 0.3^{f}$ & $\begin{array}{l}12.3 \pm \\
0.2 \mathrm{bc}\end{array}$ \\
\hline
\end{tabular}

Diameter well: $6 \mathrm{~mm}$. Acetic acid $0.1 \%$ was used as negative control ( $\mathrm{pH}$ 5); Gentamycin and cycloheximide were used as positive control. Values are means \pm standard deviation $(\mathrm{n}=3)$. Means with different superscripts $(\mathrm{a}-\mathrm{g})$ within a column indicate significant difference $(p<0.05)$.

Subsequently, the MIC and MBC were determined to compare the antibacterial potential of these compounds. As depicted in Table 4.A and 4.B, the MIC and $\mathrm{MBC}$ values fluctuate from 0.0012 to $0.039 \%$ and from 0.01 to $0.3125 \%$, respectively, against Gram (-) strains and from 0.0048 to $0.3125 \%$ and 0.019 to $1.875 \%$, respectively, toward Gram (+) strains, confirming the better inhibitory potential against the Gram (-) bacteria obtained with agar diffusion method. Similarly, among the tested samples, C120 exhibited the lowest MIC and MBC values, leading to the highest antibacterial potential, as compared to chitosan, the other high Mw-CDP $(\mathrm{C} 120>\mathrm{C} 90>\mathrm{C} 60>\mathrm{C} 30)$ and low Mw-CDP $(\mathrm{H} 120<\mathrm{H} 90<\mathrm{H} 60<\mathrm{H} 30)$. Further, the higher inhibitory potential of this sample was obtained toward P. aeruginosa, S. enterica, E. sp, followed by $S$. aureus. Furthermore, MBC values demonstrate a bacteriostatic effect that all the samples against the seven tested bacteria with a ration $\mathrm{MBC} / \mathrm{MIC} \geq 4$. 
Table 4

Minimum inhibitory (MIC) (A) and bactericide (MBC) (B) concentrations (w/v, \%) of chitosan and CDP samples, determined by liquid growth inhibition assay, against seven pathogenic bacteria.

\begin{tabular}{|c|c|c|c|c|c|c|c|}
\hline (A) & & Gram - & & Gram + & & & \\
\hline Bacteria & $\begin{array}{l}\text { Salmonella } \\
\text { enterica }\end{array}$ & $\begin{array}{l}\text { Pseudomonas } \\
\text { aeruginosa }\end{array}$ & $\begin{array}{l}\text { Enterobacter } \\
\mathrm{sp}\end{array}$ & $\begin{array}{l}\text { Staphylococcus } \\
\text { aureus }\end{array}$ & $\begin{array}{l}\text { Micrococcus } \\
\text { luteus }\end{array}$ & $\begin{array}{l}\text { Listeria } \\
\text { monocytogenes }\end{array}$ & $\begin{array}{l}\text { Bacillus } \\
\text { cereus }\end{array}$ \\
\hline Chitosan & 0.019 & 0.019 & 0.039 & 0.078 & 0.078 & 0.156 & 0.156 \\
\hline C30 & 0.01 & 0.0048 & 0.01 & 0.019 & 0.039 & 0.039 & 0.039 \\
\hline $\mathrm{C} 60$ & 0.01 & 0.0048 & 0.0048 & 0.019 & 0.019 & 0.039 & 0.039 \\
\hline $\mathrm{C} 90$ & 0.048 & 0.0024 & 0.0048 & 0.01 & 0.019 & 0.019 & 0.019 \\
\hline C120 & 0.0024 & 0.0012 & 0.0048 & 0.01 & 0.01 & 0.019 & 0.019 \\
\hline $\mathrm{H} 30$ & 0.019 & 0.01 & 0.019 & 0.019 & 0.078 & 0.039 & 0.078 \\
\hline $\mathrm{H} 60$ & 0.019 & 0.019 & 0.039 & 0.039 & 0.156 & 0.078 & 0.156 \\
\hline H9O & 0.019 & 0.019 & 0.039 & 0.078 & 0.156 & 0.156 & 0.3125 \\
\hline H120 & 0.039 & 0.039 & 0.039 & 0.078 & 0.3125 & 0.156 & 0.3125 \\
\hline
\end{tabular}

\begin{tabular}{|c|c|c|c|c|c|c|c|}
\hline (B) & & Gram - & & Gram + & & & \\
\hline Bacteria & $\begin{array}{l}\text { Salmonella } \\
\text { enterica }\end{array}$ & $\begin{array}{l}\text { Pseudomonas } \\
\text { aeruginosa }\end{array}$ & $\begin{array}{l}\text { Enterobacter } \\
s p\end{array}$ & $\begin{array}{l}\text { Staphylococcus } \\
\text { aureus }\end{array}$ & $\begin{array}{l}\text { Micrococcus } \\
\text { luteus }\end{array}$ & $\begin{array}{l}\text { Listeria } \\
\text { monocytogenes }\end{array}$ & $\begin{array}{l}\text { Bacillus } \\
\text { cereus }\end{array}$ \\
\hline Chitosan & 0.156 & 0.3125 & 0.625 & 0.625 & 1.25 & 0.625 & 0.3125 \\
\hline C30 & 0.156 & 0.078 & 0.078 & 0.156 & 0.625 & 0.625 & 0.3125 \\
\hline $\mathrm{C} 60$ & 0.078 & 0.039 & 0.039 & 0.078 & 0.3125 & 0.3125 & 0.3125 \\
\hline $\mathrm{C} 90$ & 0.039 & 0.019 & 0.019 & 0.039 & 0.156 & 0.156 & 0.156 \\
\hline $\mathrm{C} 120$ & 0.019 & 0.01 & 0.01 & 0.019 & 0.156 & 0.156 & 0.078 \\
\hline Н30 & 0.156 & 0.078 & 0.078 & 0.3125 & 0.625 & 1.25 & 0.625 \\
\hline $\mathrm{H} 60$ & 0.3125 & 0.078 & 0.156 & 0.3125 & 1.25 & 1.25 & 0.625 \\
\hline H9O & 0.3125 & 0.078 & 0.156 & 0.625 & 1.25 & 1.875 & 1.25 \\
\hline $\mathrm{H} 120$ & 0.3125 & 0.156 & 0.3125 & 1.25 & 1.875 & 1.875 & 1.875 \\
\hline
\end{tabular}

MBC values are expressed in \%.

To sum up, both the tested methods of antibacterial activity evaluation demonstrated that the average Mw of chitosan and its derivatives along with the type of the pathogenic bacterium are crucial factors affecting the reduction of bacteria growth. Interestingly, CDP with Mw ranging from 94.10 to $396.46 \mathrm{kDa}$, particularly $\mathrm{C} 120(\mathrm{Mw}=94.10 \mathrm{kDa})$, showed higher antibacterial effect than native chitosan showing very high Mw (1244.70 kDa) and CDP (H30, H60, H90 and $\mathrm{H} 120)$ with very low $\mathrm{Mw}(<4.4 \mathrm{kDa})$.

Similarly, Li et al. [38] stated that chitosan with Mw of $50 \mathrm{kDa}$ show higher antibacterial potential toward E. colithan chitooligomers with lower (3 kDa) and higher Mw (1000 kDa). Further, Sánchez et al. [2] demonstrated that the antimicrobial activity of chitooligosaccharides (COS) is clearly closely dependent on their $\mathrm{Mw}$ and decreased with its declining and that this effect was more pronounced against the Gram (-) bacteria $E$. coli than the Gram (+) strain $L$. monocytogenes. Furthermore, Jeon et al. [39] illustrated that Mw of chitosan is an important factor governing the inhibition of Gram (-) and Gram (+) bacteria and that it should be higher than or around $10 \mathrm{kDa}$ for effective inhibition. Uchida et al. [40] reported that chitosan hydrolysate obtained by partial hydrolysis of chitosan exhibited better antibacterial activity than highly hydrolyzed chitosan materials. Ueno et al. [41] reported that COS with an average Mw $<2.2 \mathrm{kDa}$, was not capable of suppressing the bacterial growth, but COS with Mw around $5.5 \mathrm{kDa}$ suppressed the growth dose dependently.

Besides, owing to its higher Mw, chitosan possesses high viscosity and low solubility, which result in decrease of its inhibitory activity. However, chitosan derivatives with lower $\mathrm{Mw}$ and viscosity and higher solubility are advantageous as antimicrobial agents compared to native chitosan [15, 17]. Further, the antibacterial activity of chitosan and CDP was demonstrated to be correlated to its positive charge which interact with the negatively charged residues of macromolecules at the surface of bacteria (cell wall, DNA, RNA ...), thus inhibiting its growth [42, 43]. The greater negative charges on the cell surface of Gram $(-)$ strains could explain their sensitivity to CDP than Gram (+) bacteria.

\subsubsection{Antifungal activity}


The antifungal potential of chitosan and CDP was further studied using agar well diffusion method. Results depicted in Table 3 showed that the tested compounds were most effective against Fusarium solani than Rhizoctonia solani. Similarly to the antibacterial activity, the same correlation between antifungal potential and chitosan Mw was observed. Indeed, C120 (Mw $=94.10 \mathrm{kDa})$ exhibited the highest antagonistic effect towards the two fungi, compared to chitosan, as well as the other high and low Mw-CDP. In the same context, Affes et al. [15] and Rahman et al. [44] demonstrated that medium MwCDP were significantly more effective than the native chitosan and low Mw-CDP. The exact mechanism of the antifungal activity of chitosan is not well-known and various hypotheses were proposed, depending on the particular type of fungus and the molecular characteristics of chitosans (Mw, $A D$ and $D P$ ) $[1,16,40$, 12].

\subsubsection{Antioxidant activity}

The DPPH and ABTS radical-scavenging activities, reducing power and total antioxidant activity of CDP were studied and compared to the chitosan and BHA. DPPH and ABTS radical scavenging activities were reported as the effective concentration needed to reduce DPPH and ABTS radicals by $50 \%$ (IC50). The reducing power was reported as the concentration needed to obtain an absorbance of $0.5\left(\mathrm{DO}_{700 \mathrm{~nm}}=0.5\right)$ and the total antioxidant potential was measured at a concentration of $5 \mathrm{mg} / \mathrm{ml}$.

Results illustrated in Table 5 showed that, the antioxidant potential of CDP was significantly higher than that of BHA but lower than that of chitosan. Moreover, the $\mathrm{Mw}$ reduction of CDP resulted in increased antioxidant activity. Indeed, $\mathrm{H} 120$ exhibited the highest antioxidant potential $(0.60,0.20,0.87$ and $240.24 \pm 1.75$ for DPPH and ABTS radical-scavenging activities, reducing power and total antioxidant activity, respectively) than the other varying Mw-CDP $(p<0.05)$.

Table 5

$\mathrm{IC}_{50}$ values of $\mathrm{DPPH}$ and $\mathrm{ABTS}{ }^{+}$radicals-scavenging, reducing power $\left(\mathrm{OD}_{700 \mathrm{~nm}}=0.5\right)$ and total antioxidant activity values of chitosan and $\mathrm{CDP}$

\begin{tabular}{|c|c|c|c|c|}
\hline Antioxidant & $\begin{array}{l}\text { DPPH } \\
I_{50}(\mathrm{mg} / \mathrm{ml})\end{array}$ & $\begin{array}{l}\text { ABTS }^{+} \\
\mathrm{IC}_{50}(\mathrm{mg} / \mathrm{ml})\end{array}$ & Reducing power $\left(O D_{700 \mathrm{~nm}}=0.5\right)$ & $\begin{array}{l}\text { Total antioxidant activity } \\
\text { (a-tocopherol }(\mu \mathrm{mol} / \mathrm{ml}) \text { ) }\end{array}$ \\
\hline BHA & $0.26^{\mathrm{A}}$ & $0.06^{\mathrm{A}}$ & $0.10^{\mathrm{A}}$ & $272.28 \pm 0.00^{A}$ \\
\hline Chitosan & $3.07^{\mathrm{G}}$ & $1.61^{\mathrm{G}}$ & $6.22^{\prime}$ & $80.46 \pm 1.28$ \\
\hline C30 & $2.69^{\mathrm{F}}$ & $0.52^{\mathrm{F}}$ & $5.22^{\mathrm{H}}$ & $114.57 \pm 1.02^{\mathrm{H}}$ \\
\hline $\mathrm{C} 60$ & $1.82^{\mathrm{E}}$ & $0.28^{\mathrm{E}}$ & $2.36^{\mathrm{G}}$ & $137.19 \pm 2.80^{G}$ \\
\hline $\mathrm{C} 90$ & $1.35^{\mathrm{E}}$ & $0.28^{\mathrm{E}}$ & $1.87^{\mathrm{F}}$ & $140.05 \pm 1.55^{\mathrm{FG}}$ \\
\hline C120 & $1.33^{\mathrm{DE}}$ & $0.26^{\mathrm{DE}}$ & $1.85^{\mathrm{F}}$ & $143.33 \pm 0.97^{F}$ \\
\hline H3O & $0.85^{C D}$ & $0.24 \mathrm{CD}$ & $1.65^{\mathrm{E}}$ & $170.12 \pm 2.35^{\mathrm{E}}$ \\
\hline H60 & $0.71^{\mathrm{BCD}}$ & $0.23^{\mathrm{BCD}}$ & $0.99^{D}$ & $179.23 \pm 2.45^{D}$ \\
\hline H90 & $0.63^{B C}$ & $0.21^{\mathrm{BC}}$ & $0.95^{\mathrm{C}}$ & $231.52 \pm 0.77^{C}$ \\
\hline $\mathrm{H} 120$ & $0.60^{\mathrm{B}}$ & $0.20^{B}$ & $0.87^{\mathrm{B}}$ & $240.24 \pm 1.75^{B}$ \\
\hline
\end{tabular}

Values are means \pm standard deviation $(\mathrm{n}=3)$. Means with different letters $(A-l)$ and within a column indicate significant difference $(p<0.05)$.

Similar results, in vitro, were reported by Zhou et al. [19], who stated that chitosan oligomers obtained by chitosan hydrolysis using ChiEn3 chitinase exhibited better DPPH scavenging activity than the undigested chitosan. Further, Laokuldilok et al. [20] observed that COS with Mw of $5.1 \mathrm{kDa}$ possess better DPPH radical activity than chitosan and COS with 14.3 and $4.1 \mathrm{kDa}$. As well, the increase of the antioxidant activity towards ABTS of low Mw-CDP, in comparison with chitosan and high Mw-CDP, was in accordance with those reported by Affes et al. [15] and Chang et al. [45]. Furthermore, Huang et al. [46] and Laokuldilok et al. [20] demonstrated that lower Mw chitosan derivatives showed greater reducing power capacity.

The lower antioxidant potential of high Mw-CDP was mainly due to their higher inter and intramolecular bonding and compact structure which restrict the chance of exposure of their amine groups [1].

\section{Conclusion}

Current attention on chitosan focuses to its derivatives because of their advantages, including its reduced Mw and water-solubility. In this work, we showed that the chitosan chemical depolymerization, during $2 \mathrm{~h}$ using $\mathrm{HCl}$, is a simple and practical method to produce high and low Mw-CDP at different hydrolysis times. The obtained chitosan derivatives, with reduced $\mathrm{Mw}$, viscosity and crystallinity and higher solubility have been demonstrated, as compared to the native chitosan, to possess better antibacterial, antifungal and antioxidant effects, which were found to be influenced by their Mw, among other factors. Interestingly, such depolymerization process may be considered as a promising method for the preparation of effective varying Mw chitosan derivatives to be used as functional food additives and natural food preservatives for food-processing applications.

\section{Declarations}


Ethical Approval: Not applicable.

Consent to Participate: The authors declare that they consent to participate.

Consent to Publish: The authors declare that they consent for publication.

\section{Authors Contributions:}

Sawsan Affes: Conceptualization, Methodology, Validation, Formal analysis, Investigation, Writing-Original Draft. Hana Maalej: Supervision, Conceptualization, Resources, Writing-Review \& Editing. Inmaculada Aranaz: Conceptualization, Resources, Writing-Review \& Editing, Niuris Acosta: Resources, Visualization, Writing-Review \& Editing. Angeles Heras: Resources, Visualization, Writing-Review \& Editing. Moncef Nasri: Supervision, Resources, Visualization, Writing-Review \& Editing. All authors read and approved the manuscript.

Funding: This work was funded by the Ministry of Higher Education and Scientific Research, Tunisia. The authors gratefully acknowledge financial support provided by the Spanish Ministry of Economy and Competitiveness [Grants MAT2015-65184-C2-1-R].

Competing Interests: The authors declare that there are no conflicts of interests.

Availability of data and materials: Not applicable.

\section{References}

1. Avelelas F, Horta A, Pinto LFV, Marques SC, Nunes PM, Pedrosa R, and Leandro SM. (2019) Mar. Drugs. 17, 239.

2. Sánchez Á, Mengíbar M, Rivera-Rodríguez G, Moerchbacher B, Acosta B, and Heras A. (2017) Carbohydr. Polym. 157, $251-257$.

3. Dash M, Chiellini F, Ottenbrite RM, and Chiellini E. (2011) Prog. Polym. Sci. 36, 981-1014.

4. Rajoka MSR, Zhao L, Mehwish HM, Wu Y, and Mahmood S. (2019) Appl. Microbiol. Biotechnol. 103, 1557-1571.

5. Puvvada YS, Vankayalapati S, and Sukhavasi S. (2012) Int. Curr. Pharm. J. 1, 258-263.

6. Affes S, Maalej H, Aranaz I, Acosta N, Kchaou H, Heras Á, and Nasri M. (2020) Carbohydr. Polym. 236, 116063.

7. Santos-Moriano P, Kidibule PE, Alleyne E, Ballestros AO, Heras A, FernandezLobato M, and Plou FJ. (2018) Process Biochem. 73, $102-108$.

8. Kim SK, and Rajapakse N. (2005) Carbohydr. Polym. 62, 357-368.

9. Santoso J, Adiputra KC, Soerdirga C, and Tarman K. (2020) IOP Conference Series: Earth and Environmental Science (EES), $414,012021$.

10. Yuan X, Zheng J, Jiao S, Cheng G, Feng G, Du Y, and Liu H. (2019) Carbohydr. Polym. 220, 60-70.

11. Li K, Xing R, Liu S, Li R, Qin Y, Meng X, and Li P. (2012) Carbohydr. Polym. 88, 896-903.

12. Younes I, Sellimi S, Rinaudo M, Jellouli K, and Nasri M. (2014) Int. J. Food Microbiol. 185, 57-63.

13. Zaeni A, Safitri E, Fuadah B, and Sudiana IN. (2017) J. Phys. Conf. Ser. 846, 012011.

14. Kasaai R, Arul J, and Charlet G. (2008) Ultrason Sonochem. 15, 1001-1008.

15. Affes S, Maalej H, Aranaz I, Acosta N, Heras Á, and Nasri M. (2020) Int. J. Biol. Macromol. 144, 279-288.

16. Song YS, Seo DJ, and Jung WJ. (2019) Microb. Pathog. 129, 277-283.

17. Wang Y, Peigen Z, Yu J, Pan X, Wang P, Lan W, and Tao S. (2007) Asia Pac J Clin Nutr. 16, 174-177.

18. Pan M, Li J, Lv X, Du G, and Liu L. (2019) Enzyme Microb Tech. 124, 54-62.

19. Zhou J, Dai R, Wang Y, Li M, Zhu Y, Chen L, Kang L, Liu Z, Yang Y, and Yuan S. (2019) Carbohydr. Polym. 207, 729-736.

20. Laokuldilok T, Potivas T, Kanha N, Surawang S, Seesuriyachan P, Wangtueai S, Phimolsiripol Y, and Regenstein JM. (2017) Food Biosci. 18, $28-33$.

21. Lee DX, Xia WS, and Zhang JL. (2008) Food Chem. 111, 291-295.

22. Tømmeraas, K., Vårum, K.M., Christensen, B.E., and Smidsrød O. (2001) Carbohydr. Res. 333, 137-44.

23. Aljbour ND, Beg DH, and Gimbun J. (2019) Chem. Eng. Technol. 42, 1741-1746.

24. Cabrera JC, and Van Cutsem P. (2005) Biochem. Eng. J. 25, 165-172.

25. Affes, S, Aranaz I, Hamdi M, Acosta N, Ghorbel-Bellaaj O, Heras Á. (2019) Int. J. Biol. Macromol. 139, 558-569.

26. Nawani NN, and Kapadnis BP. (2005) Process Biochem. 40, 651-660.

27. Muzzarelli RA, Rocchetti R, Stanic V, and Weckx M. (1997) in: R.A.A. Muzzarelli, M.G. Peter (Eds.), Chitin Handbook Grottammare, Atec, $109-119$.

28. Rinaudo, M, Milas M, and Dung PL. (1993) Int. J. Biol. Macromol. 15, 281-285.

29. Fernandez-Kim, S.O. (2004) Graduate Faculty of Seoul National University, Dissertation of Master of Science, 107.

30. Focher, B, Beltrame, PL, Naggi A, and Tori, G. (1990) Carbohydr. Polym., 12, 405-418.

31. Vanden Berghe, D.A., Vlietinck, A.J. (1991) Meth. Plant Biochem. 6, 47-69.

32. Farag, RS, Daw, ZY, Hewedi, FM, and El-baroty, GSA. (1989) J. Food Prot. 52, 665-667.

33. Bersuder, P, Hole, M, and Smith, G. (1998) J. Am. Oil Chem. Soc. 75, 181-187.

34. Re, R, Pellegrini, N, Proteggente, A, Pannala, A, Yang, M, and Rice-Evans, C. (1999) Free Radic. Biol. Med. 26, 1231-1237.

35. Yildirim, A, Mavi, A, and Kara, AA. (2001) J. Agric. Food Chem. 49, 4083-4089.

Page $10 / 12$ 
36. Prieto, P, Pineda, M, and Aguilar, M. (1999) Anal Biochem. 269, 337-341.

37. Li, J, Du, Y, Yang, J, Feng, T, Li, A, and Chen, P. (2005) Polym. Degrad. Stab. 87, 441-448.

38. Li, XF, Feng, XQ, Yang, S, Fu, GQ, Wang, TP, and Su, ZX. (2010) Carbohydr. Polym. 79, 493-499.

39. Jeon, YJ., Park, PJ., and Kim, SK. (2001) Carbohydr. Polym. 44, 71-76.

40. Uchida, Y., Izume, M., and Ohtakara, A. In Braek, G.S., Anthonsen, T., and Sandford P. (1989) Chitin and Chitosan: Sources, Chemistry, Biochemistry,

Physical Properties and Applications. 372-382.

41. Ueno, K., Yamaguchi, T., Sakairi, N., Nishi, N., and Tokura, S. (1997) In A. Domard, G. A. F. Roberts, \& K. M. Varum, Advances in Chitin Science. $156-161$.

42. Shahidi, F, Arachchi, JKV, and Jeon, YJ. (1999) Trends Food Sci. Technol. 10, 37-51.

43. Vishu Kumar, AB., Varadaraj, MC., Gowda, LR., and Tharanathan, RN. (2007) BBA-Gen. Subjects. 1770, 495-505.

44. Rahman, MH., Hjeljord, LG., Aam, BB., Sørlie, M., and Tronsmo, A. (2014) Eur. J. Plant Pathol. 141, 147-158.

45. Chang, CT., Lin, YL., Lu, SW., Huang, CX., Wang, YT., and Chung, YC. (2016) PLoS One. 11, 1-17.

46. Huang, J., Zhao, D., Hu, S., Mao, J., and Mei, L. (2012) Carbohydr. Polym. 87, 2231-2236.

\section{Figures}

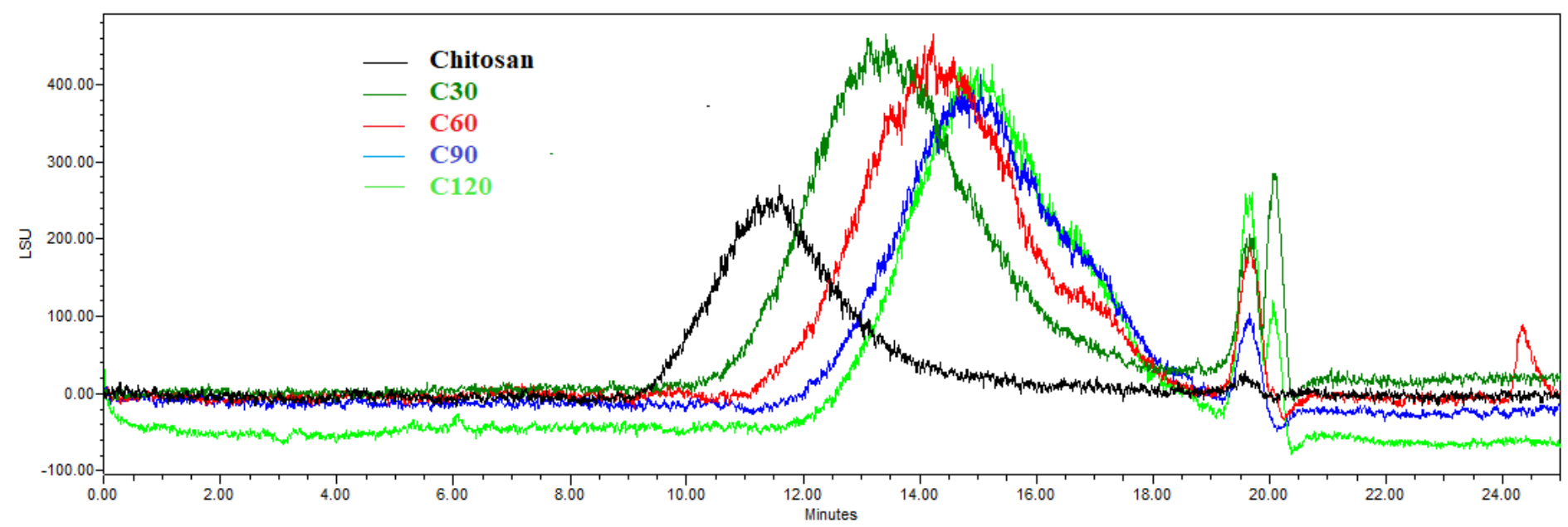

Figure 1

SEC-HPLC chromatograms of chitosan and its derivatives (C30, C60, C90 and C120) obtained by chitosan depolymerization.

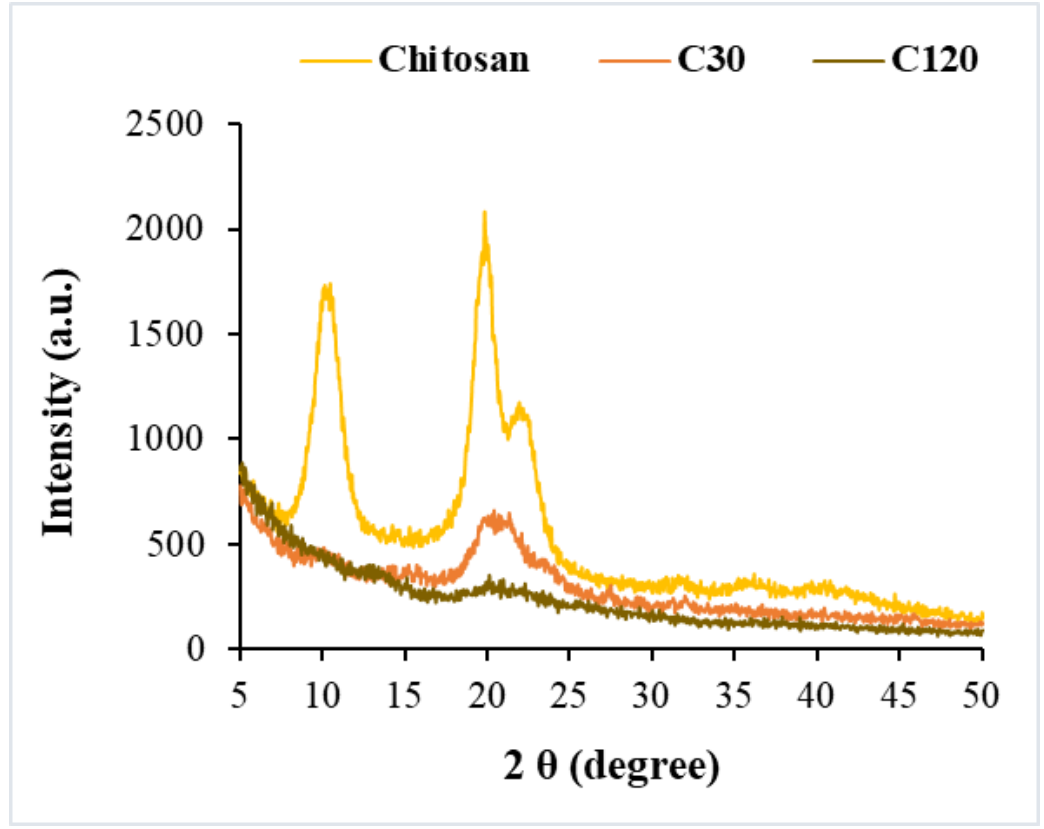

Figure 2

X-ray diffractograms of chitosan and its derivatives (C30 and C120). 


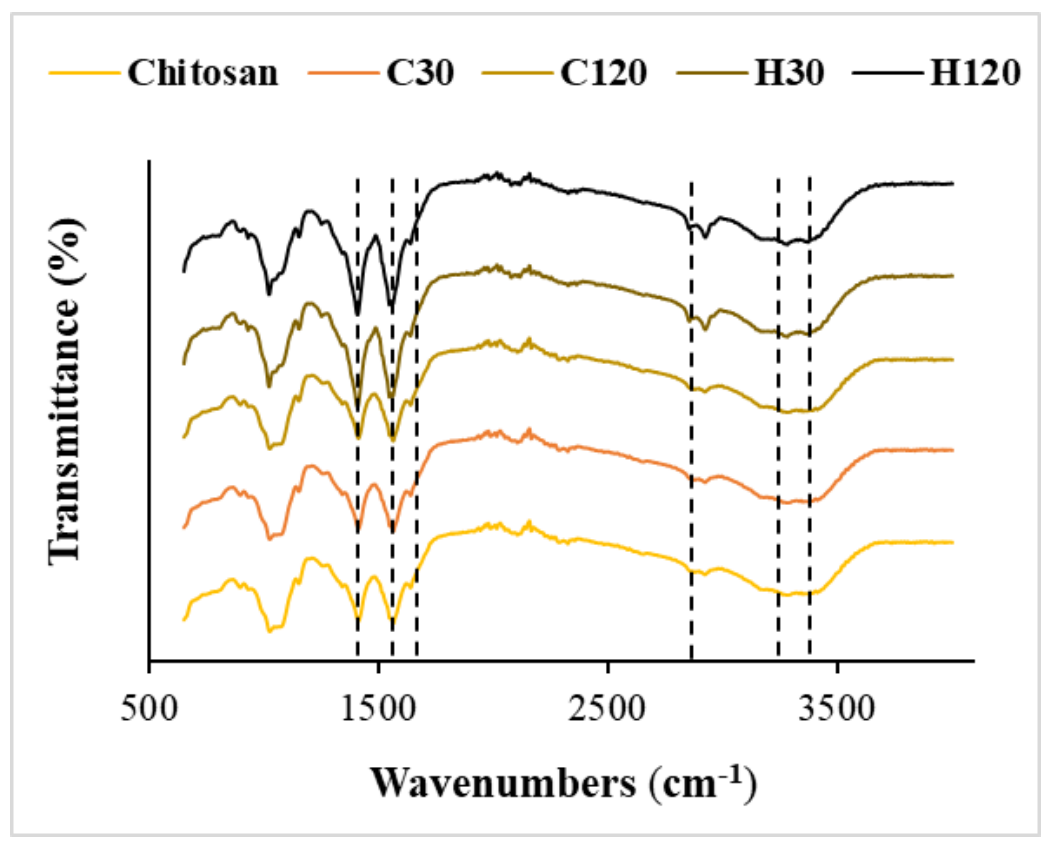

Figure 3

FTIR spectra of chitosan and its derivatives obtained after 30 min and 120 min (C30, C120, H30 and H120).

\section{Supplementary Files}

This is a list of supplementary files associated with this preprint. Click to download.

- SuppFig1.jpg

- GraphicalAbstract.pdf 